Snežana Mihajlov ${ }^{1}$

Velimir Dedić ${ }^{2}$

Dobrica Radovanović ${ }^{3}$

Nenad Mihajlov ${ }^{4}$
JEL: M540

DOI: $10.5937 /$ industrija41-3475

Original Scientific Paper

\title{
The differences in job satisfaction among employees in public and private enterprises in Serbia
}

Article history:

Received 24 February 2013

Sent for revision 12 March 2013

Received in revised form 20 March 2013

Accepted 01 April 2013

Available online 15 April 2013

\begin{abstract}
The aim of this paper is to show the sector differences in job satisfaction among employees in Serbian enterprises. Based on the empirical and theoretical findings, it was shown that the employees in public enterprises in Serbia are more satisfied with their job than their counterparts in the private sector, which presents a general trend characteristic of countries where research of this type was carried out. In addition, it was pointed out to the general trend in preference of the employment of employees in public enterprises, that is, the abandonment of the private sector of the economy. It was shown that the effects of the economic crisis in the country, together with incomplete adjustment to the new market conditions in the field of labour and employment relations, determine job certainty as one of the most important factors in shaping employee satisfaction which contributes to decision making about staying in or leaving an organization.
\end{abstract}

Key words: sector, satisfaction among employees, general trend, employees in public, public enterprises, private sector, job satisfaction, differences in job satisfaction

Apstrakt: Cilj rada je da ukaže na sektorske razlike u zadovoljstvu poslom kod zaposlenih u srpskim preduzećima. Na osnovu empirijskih i teorijskih nalaza dokazano je da su zaposleni u državnim preduzećima u Srbiji zadovoljniji poslom od svojih kolega u privatnom sektoru poslovanja što predstavlja opšti trend karakterističan i za zemlje u kojima su obavljena istraživanja ovog

\footnotetext{
${ }^{1}$ Prof. dr Snežana Mihajlov, Business School of Applied Studies, Blace, snezanamihajlov@hotmail.rs

${ }^{2}$ Prof. dr Velimir Dedić, Modern Business School, Belgrade

${ }^{3}$ Business School of Applied Studies, Blace

${ }^{4}$ Nenad Mihajlov, Faculty of Business and Industrial Management, Belgrade
} 
Mihajlov, Dedić, Radovanović, Mihajlov: The differences in job satisfaction among...

tipa. Osim toga ukazano je na preferenciju zaposlenih ka zapošljavanju u državnim preduzećima, odnosno napuštanju privatnog dela privrede. Pokazalo se da efekti ekonomske krize u kojoj se zemlja nalazi uz nepotpunu prilagođenost novim tržišnim okolnostima u svetu rada $i$ radnih odnosa determinišu sigurnost posla kao jedan od najznačajnijih činilaca u oblikovanju zadovoljstva zaposlenih koji doprinosi donošenju odluke o ostajanju ili napuštanju organizacije.

Ključne reči: sektor, zadovoljstvo zaposlenih, opšti trend, zaposleni u javnim preduzećima, javna preduzeća, privatni sektor, zadovoljstvo poslom, razlike $u$ zadovoljstvu poslom.

\section{Introduction}

The increased interest for the job satisfaction phenomenon, both in academic research and in business practice, arises from the perception of the significant implications of the employee's positive attitudes about different aspects of organization effectiveness. Positive attitudes cause lower levels of absenteeism, higher levels of employee motivation and greater loyalty to the organization, whereas negative attitudes imply less devotion and motivation, a greater level of absence form work and a greater possibility of leaving the organization. Growing interest is also justified by the fact that people and their knowledge in modern business conditions are the crucial source for building and maintaining competitive advantage. Previous research shows that the intensity of the effect of certain factors on the job satisfaction level among the employees is also determined by the sector in which business is performed, which will be the subject of this paper.

\section{Factors which determine the level of job satisfaction}

Job satisfaction is considered one of the most studied constructs in organizational behaviour due to continuous interest of scholars for subjective evaluation of the working conditions, manager and researcher for its final organizational results, such as organizational committment, absenteeism, fluctuation or the employees' intentions in leaving the organization. By noticing the great effects which are realized in an organization, job satisfaction represents a multidisciplinary and an eternal concept applicable to all professions, jobs and contexts. Despite some controversial views, job satisfaction is, nevertheless, recognized as a crucial factor in work productivity. 
Job satisfaction is "... an individual's attitude towards his job. Job satisfaction is the result of matching the objective conditions and the individual's expectations." (Ivancevich, Olekalns \& Matteson, 1997, p. 86).

Conceptually, it is about a wider construct which is concerned with all or most characteristics of the job and the working environment, within which the employees are rewarded, fulfilled and satisfied, that is, frustrated or dissatisfied (Weiss, 2002). All previous arguments are based on a generally accepted assumption that the overall job satisfaction is related to the complex set of mutual relationships between tasks, roles, responsibilities, interactions, incentives and rewarding employees (Bowling \& Hammond, 2008).

Two approaches are used for determining and measuring job satisfaction: the holistic and the indirect (additive) approach.

The holistic approach defines satisfaction as an affective relationship in which an individual's love towards the job is expressed through his attachment to work, committment to work and the importance the job has for him. According to the indirect (additive) approach, general job satisfaction is the sum of satisfactions of individual aspects of the job which contribute to the total satisfaction to the degree which is significant for the individual. The list of factors which realize the effect on the job satisfaction degree differs among authors, but they all have in common the organizational conditions and personal characteristics of an individual.

Kates says that job satisfaction consists of several dimensions: attachemnt to a group, intrinsic satisfaction which results from performing certain tasks, the feeling of belongning to a work organization, satisfaction with the material status and job status (Kates, 1950). Sheridan and Slocum (1975) determined a ranking of what workers most want at work. The first place belongs to „the possibility for the job to be carried out well“, and the second to „a manager who wants to listen and help the worker“. After „being paid according to the competences“, "the possibility for promotion" and „being paid by unit“, „good associates" take the sixth position. A Research Report by the Society for Human Resource Management - SHRM) for 2011 lists the following as the most important apsects of professional satisfaction: job safety and the possibility of using own knowledge and competences; financial stability of an organization; relationships with the superiors; reimbursement/salary and the content of the job (Weiss, 2002). As opposed to this, Herzberg considers job satisfation only as a product of job content, an opportunity for an individual to express himself through work, to develop his capacities and self-respect; other factors, such as the salary, managment style, interpersonal relationships and job safety can only contribute to the absence of dissatisfaction, but they do not have the strength to create the feeling of satisfaction (Herzberg, Mausner, \& Sniderman, 1959). 
When conducting the study on a sample of university workers, Matanovic determined that personality dimensions, especially pleasantness and neuroticism, can predict job satisfaction (Matanović, 2009). Lately, there have been studies which examine the mutual effect of job satisfaction and life satisfaction. Researchers assume that three possible forms of their relationships exist: 1) overflowing, when work experience overflows in the non-working life and vice versa; 2) segmentation, when work and life experience are separate and have little connection one to another; 3) compensation, when an individual seeks compensation for work dissatisfaction by fulfillment and happiness in his life outside the work place and vice versa. Judge and Watanabe (Judge \& Watanabe, 1994) found, based on the sample which covered the American employees, that $68 \%$ belong to the overflow group, $20 \%$ belong to the segmentation group and $12 \%$ to the compensation group. Based on these results, the authors concluded that there is a great degree of connection between life and work satisfaction.

Understanding job satisfaction among employees can help in explaining organizational performances, productivity, absenteeism, fluctuation and other organizational issues. The most mentioned consequences of job satisfaction are greater work productivity, increase in employee loyoalty, less absence from work, high motivation for satisfying users' needs and improving the organization's image (Ghinetti, 2006). According to other authors, the most common effects of the achieved job satisfaction are high motivation for work, involvement in work, positive organizational behaviour of employees, high organizational commitment, less absenteeism, fluctuation and sress, high organizational performance and job performanc, high satisfaction with the overall life and good health of employees (Kreitner, Kinicki \& Buelens, 1999).

Because of its significant effects on the organizational results and behaviour of employees, the interest for investigating job satisfaction hasn't decreased. In our conditions, however, the most characteristic are educational testing of job satisfaction, whereas there is almost no big research of job satisfaction in enterprises or certain branches of economy. An exception is the research of job satisfaction in health workers which has recently become regular on the territory of the Republic of Serbia, due to the delicacy of the profession. In order to promote job satisfaction as an important role in understanding employee behaviour and realizing organizational perforance, this paper presents an important contribution in cognition of those factors which affect the differences in the degree of realized job satisfaction among employees in the public and private sector. First of all, the paper will show previous European experience regarding the differences in the public-private job satisfaction, and then the basic characteristics of the labour market in Serbia in the previous decade. 


\section{Earlier research of sector differences in job satisfaction}

Recent empirical research indicates significant differences in the levels of job satisfaction among employees in the public and private business sector (Table 1). Despite the fact that the degree and sign of the gap between the private-public job satisfaction can be justified by specificities of the institutional framework of the country, employees in the public sector are more satisfied than their colleagues in private enterprises (for example, Germany, Greece, Italy, Great Britain). By examining different job dimensions, a certain number of those that affect the creation of sector satisfaction difference was identified. Research conducted in Greece shows that employees in the public sector are more willing to accept a decrease in salary of $4.5 \%$ in order to avoid a job in private enterprises (Kioulafas, Donatos, \& Michailidis, 1991), while in Italy, public employees are more satisfied with their jobs $3.5 \%$ on average than their colleagues in the private sector due to largely better working conditions (Ghinetti, 2006). According to the study results, greater salaries, financial and non-financial benefits, as well as the possibility of bribery affect a higher degree of job satisfaction among employees in the public business sector (Demoussis \& Giannakopoulos, 2007; Luechinger, Meier \& Stutzer, 2008; Papapetrou, 2006).

Table1 - The list of economic studies about the differences in the public-private job satisfaction

\begin{tabular}{|c|c|c|}
\hline Study & Country & Results \\
\hline $\begin{array}{l}\text { Heywood, Siebert, Wei } \\
\text { (2002) }\end{array}$ & Great Britain & $\begin{array}{l}\text { greater salary satisfaction among the } \\
\text { employed in the public sector }\end{array}$ \\
\hline Clark, Senik (2006) & France and Great Britain & $\begin{array}{l}\text { greater salary satisfaction among the } \\
\text { employed in the public sector }\end{array}$ \\
\hline $\begin{array}{l}\text { Demoussis, Giannakopou- } \\
\text { los(2007) }\end{array}$ & Greece & $\begin{array}{l}\text { greater general job satisfaction and } \\
\text { satisfaction with all job aspects among } \\
\text { the employed in the public sector } \\
\text { greater salary satisfaction among the }\end{array}$ \\
\hline Ghinetti (2007) & Italy & $\begin{array}{l}\text { employed in the public sector and all } \\
\text { non-financial job aspects }\end{array}$ \\
\hline $\begin{array}{l}\text { Luechinger, Stutzer, Win- } \\
\text { kelmann(2006) }\end{array}$ & $\begin{array}{l}20 \text { countries in central } \\
\text { and eastern Europe }\end{array}$ & $\begin{array}{l}\text { greater salary satisfaction among the } \\
\text { employed in the public sector }\end{array}$ \\
\hline $\begin{array}{l}\text { Luechinger, Meier, Stutzer } \\
\text { (2008) }\end{array}$ & $\begin{array}{l}25 \text { European and } 17 \\
\text { South-American countries }\end{array}$ & $\begin{array}{l}\text { in most contries, greater salary satis- } \\
\text { faction among the employed in public } \\
\text { enterprises }\end{array}$ \\
\hline $\begin{array}{l}\text { Luechinger, Stutzer, Win- } \\
\text { kelmann(2010) }\end{array}$ & Germany & $\begin{array}{l}\text { negative selection of the employed in } \\
\text { the public sector }\end{array}$ \\
\hline
\end{tabular}

Job safety is also stated as an important determinant of sector differences in job satisfaction, especially during economic recessions or unstable economic situations in the country. Job unsafety as a subjective, psychological phenomenon is characterized primarily by the feeling of uncertainty about future 
employment. Unlike real job loss, job unsafety refers to the anticipation of a stressful event, in such a way that the nature and the continuous existence of the job are considered risky (Sverke \& Hellgren, 2002). The public and the private sector differ significantly according to the objective job safety for the following reasons (Clark \& Senik, 2006):

(1) employees in public enterprises are often legally protected from being dismissed. For instance, in Germany, job contracts for public employees are defined by a special Law according to which the employed have a very strict business protection since they can be dismissed only if they are convicted of a crime;

(2) the decreased sensitivity among the employed in the public sector about economic shocks is the consequence not only of the precisely made job contracts, but also the weaker financial pressure on the need to decrease the unemployment rate in this sector. While private enterprises can go bankrupt, this is not easily the case with the public ones, despite maintaining high employment rate which is most often justified as a countermeasure for the economic crisis. Beside the fact that the line-ups for finding a job in the public enterprises during recession are getting bigger, a high rate of unemployment which implies a lower degree of business certainty leads individuals to look for a more certain (that is, public) job. In accordance with this idea, a reasearch which included French people between the ages of 20-30 showed that three quarters of the young are looking for a job in the public sector at times when the unemployment rate of younger people is much higher than the already high general rate of unemployment of $10 \%$. The respondents explicitly stated that the only reason for employment in public enterprises is a greater job safety (Clark \& Senik, 2006). Young people in Serbia are also looking for safety and certainty in business. According to a research Citizens' initiative, around $40 \%$ of the respondents would choose a safe, even a worse paid job, $33 \%$ would choose to own a business, while $27 \%$ of the respondents would choose a well-paid and less safe job. Nevertheless, job safety is recognized by both in the public administration that is the public sector. Therefore, $57 \%$ of the respondednts think that employment in public administration is safe, that is $44 \%$ consider it to be the best professional experience (TNS Medium Gallup, 2008). On the other hand, due to a general belief that entrepreneurs do not earn enough in comparison to the invested work and the risk they undergo, $37 \%$ of young people would not leave the public service under any circumstances. At the same time, research of the labour market shows the significant differences in the salaries in the private and the public sector. Employees in Greek public enterprises earn significantly more than their colleagues in the private sector, whereby the discrepancy in the salaries cannot be attributed to greater education or experience of public sector workers (Kioulafas, Donatos \& Michailidis, 1991). Data shows that men in public enterprises earn $19 \%$ more than their colleagues in the private sector on average, while the differ- 
ence in salaries among women reach even 42\% (Kanellopoulos, 1997). Because the salaries in the public sector, especially in public administration, are increased by different types of bonuses for the realized productivity, reimbursements for work in committees of work groups and/or social work, the interest for jobs in public enterprises goes beyond the realistic capacities of this business sector (Papapetrou, 2006). Salaries in the public sector do not undergo great oscillations in relation to the unemployment rate, which furthermore loads the great state apparatus (Clark \& Postel-Vinay, 2009).

The aforementioned results allow us to make the following hypothesis:

$\mathrm{H} 1$ : Employees in public enterprises are more satisfied with their jobs than employees in the private sector.

Based on the author's claims which indicate a positive correlation between the general job satisfaction and the salary satisfaction and business safety, we can hypothesize that greater job satisfaction among employees in the public sector results partially from the satisfaction with the aforementioned job aspects.

$\mathrm{H} 2$ : Employees in public enterprises are more satisfied with their salary than employees in the private sector.

H3: Employees in public enterprises are more satisfied with their job security than employees in the private sector.

In accordance with this, research will be aimed at the direction.

\section{Characteristics of the labour market in Serbia}

In the beginning of the new millenium, Serbia entered the process of transition with the intent to adjust the economy to the business market principles. Positive effects in the field of economic growth which were realized up to the beginning of the global economic crisis were not used properly, that is they were not turned into creating a sufficient number of new jobs. A great decrease in the number of the employed in that period in public enterprises was not absorbed by an adequate increase of employment in the private sector.

Low productivity and absence of the correlation of the results with job evaluation in the socialist regime caused an inefficient market business. Because of that, the transition process had a task to create proprietary management and the entrepreneurial spirit of business. After 2001, a great number of public enterprises was privatized, which contributed to the change in the ownership structure of the Serbian economy, but not to the creation of a stable economic environment. Prior to the ownership transformation of economic subjects, the sectoral structure of the employed in Serbia was as follows: $76,9 \%$ of the total 
number of employed was in the public sector, while only $19,5 \%$, that is $3,7 \%$, worked in the private sector or in mixed ownership enterprises.

However, in the period from 2004 to 2009, the number of workers in the private sector increased $28 \%$, together with an increase in the employment rate in public ownership enterprises (10\%). A lower increase in the number of employees was noted in the social ownership enterprises (13\%), that is, in other forms of ownership (25\%). A dynamic employment growth in the small and medium enterprises sector, where around 200,000 new workers were employed in the period from 2004 to 2008 (Republic agency for development of SME and entrepreneurship, 2008, p.9.), significantly neutraliized the decrease in the number of the employed in large enterprises due to the restructuring process and contributed to the decrease of social tension in the country, although it was insufficient to absorb the overall excess of manpower and, therefore, the unfavorable trends in the labour market were continued. At the same time, due to restructuring, bankruptcy and privatization of public (social) enterprises, a great number of employees (nearly $3 / 4$ ) voluntarily or involuntarily lost their jobs on various grounds (redundancy, pension, job contract termination or social program) without the measures of the state to increase their level of employment. The growth of the private sector did not enable the creation of a sufficient number of jobs and absorbtion of the labour force inflow from the restructured enterprises, but rather created a series of negative effects in the form of work rights decrease, social insecurity and numerous dismissals. Privatization, which as a consequence had an absence of economic activity which was supposed to generate new jobs, caused a job market characteristic of a high unemployment rate, low employment share in the private sector and insufficient mobility of manpower.

Due to the effects of the global financial crisis and the fact that a great number of small and medium enterprises could not survive, the number of the employed in 2009 in this sector was lowered for 7.2\% (Republic agency for development of SME and entrepreneurship, 2009, p.10), which caused the interruption of the positive trend in the employment increase in the private sector. The number of employees in public enterprises was moving the opposite direction because a mild increase in employment $(0.46 \%)$ was noted, especially in energetics, state administration and social insurance, health and education. According to the data from the Survey on manpower (Statistical office of the Republic of Serbia, 2011], in $201052.9 \%$ of employees was registered in private enterprises, that is $47.1 \%$ in all other forms of ownership, which indicates that after the process of ownership structure change of economic subjects, there is nearly a half of employees outside the private part of the economy. Besides $1.6 \%$ of employed workers in the non-registered private ownership, the rest of the employed is still working in public enterprises $(43.2 \%)$, social enterprises (2.9\%) and other forms of ownerships (1.0\%) (Statistical Office of the Republic of Serbia, 2011). 
Data for previous year indicate the continued trend deterioration on the labour market - the fall in the employment rate and an even grearer growth of unemployment rate. The overall fall in employment in the previous year continues further in the private sector unlike employment in the public sector which remains almost unchanged. Nowadays, around 550.000 people work in the public sector, that is over a quarter of the formally employed which represents a great burden for the development of the whole economy.

Figure 1 - Number of employees in Serbia according to the business sector from 2004 to 2011

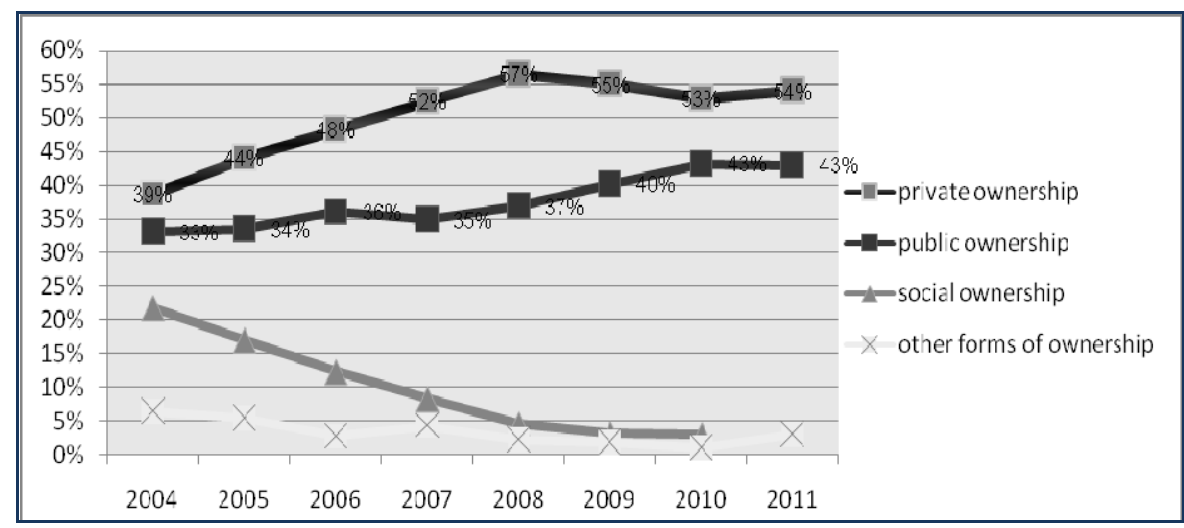

The interest for employment in the public sector in comparison to the private is also seen through the salary. The average value of gross earnings in 2009 was 44.147 dinars, where earnings which are below the average were noted in agriculture, industry, trade and other branches which are fully or greatly privatized (Official Gazette, 2005).

On the other hand, earnings above the average were realized in public administration, mining and energetics, that is, the economic branches which in great part were not privatized and the carriers of which are usually state enterprises. The average realistic earning in Serbia in the last quarter of 2011 continues to grow, this time for $2.9 \%$. The greatest salary was reported to be in public enterprises $(7.3 \%)$, while salaries in economy (private, social and mixed enterprises) grew $3.3 \%$. The growth of earnings in economy can be explained by the increase of the minimal wage which, for the greatest part, is earned by the employees in the private sector.

Salaries in public enterprises grew more than two times in comparison to the salaries in private enterprises and the general public sector. The increase was caused by freeing salaries in the end of 2010, after which bonuses, regresses and delayed salaries followed. However, even before this increase the earn- 
ings in public enterprises were bigger than the ones in the private sector. Anthough there is no empirical proof, anecdotal evidence suggests that individuals with equal qualifications receive much greater earnings in public enterprises than the employed in the private sector. This says a lot about the dual character of the Serbian labour market, that is, the existence of a sector with relatively safer and better paid jobs (public enterprises) and the private sector with unstable and less paid jobs and weak protection of workers' rights. A great difference in the standards of employees in the public sector and the private sector represents a source of not only fiscal problems, but also distinct negative effects on the economic growth and economic activity. This situation creates a negative system of incentives which hampers private initiative and entreprenurial spirit as basic sources of sustainable economic growth and development. Especialy as employees in the public sector, beside financial privileges, also have other great advantages in comparison to the private sector, such as job safety or strict respect of the guaranteed workers' rights.

\section{Methodological framework for research}

In order to conduct a comparative analysis of employee satisfaction in the private and the public sector, in the period from November 2011 to January 2012, research was carried out by using a sample which encompassed several companies of different activites in private ownership and one enterprise in public ownership (Pension and Disability Fund of the Republic of Serbia). Research methodology was chosen in accordance with the defined research goal and it was based on a combination of qualitative and quantitative methods, as well as comparison with the relevant references and scientific knowledge. Data was collected through a survey, by using previously created questionnaires which were completed by more than 200 randomly chosen respondents.

The questionnaire was created in such a way to obtain information about the examined variables of certain aspects of employee satisfaction: direct cooperation with colleagues, manager's support, interpersonal relationships, opportunities for education and promotion, work organization, etc. The questions in the questionnaire primarily refer to the examination of the perception and attitudes of the employed about the organizational determinants of employee satisfaction, general job satisfaction and the possible job change. The research was carried out on a random sample of 241 employees, 166 employed in branches of the Pension and Disability Fund of the Republic of Serbia in Belgrade, Kruševac, Niš and Zaječar, 91 employed in the private sector for informatics and publishing. 75 men and 166 women were questioned, that is, 18 manager ( 5 men and 13 women) and 223 employees (70 men and 153 
women). The age range among managers was from 29 to 58 , while among employees from 26 to 63 . The average age of the respondents was 41 .

The limitation in the research can be represented by the fact that it was conducted during the times of the global economic recession, which in great part affects not only the adaptation of the enterprise to different business conditions, but also the employees' efforts to preserve the existing work status. The limitation can also refer to the research sample. Unfortunately the lack of research staff from other public enterprises, privatized state-owned enterprises and multinational companies do business in Serbia.

\section{Research results}

The starting hypothesis in research was that the employed in public enterprises were more satisfied with their jobs than their counterparts in the private sector. Based on the Chi-Square Tests we see that the distribution of responses to the question of general job satisfaction is not independent of the sector respondents, that sector affects how it fits (which is a common response). We can conclude, looking at the table, that were employed in the public enterprises generally satisfied with their jobs than their counterparts in the private sector which represents a general trend characteristic for countries where research of this type was carried out.

The question „How satisfied with your job are you taking everything into consideration?" was answered by $76 \%$ respondents in public enterprises and $55 \%$ in the private sector express general job satisfaction, which creates a difference of $21 \%$. Except the greater general job satisfaction among respondents in the public sector in comparison to the employed in private enterprises, public workers are more satisfied with all individual job aspects, and the only exception of a slightly higher degree of satisfaction with working conditions, opportunities for education and the choice of personal way of work was noted among respondents in the private sector. Employees in public enterprises are more satisfied with direct cooperation with their colleagues, interpersonal relationships in the organization, interaction with managers, information within the organization, work organization, job promotion and salary. Despite the satisfaction of more than a half of the respondents from private enterprises, the number of dissatisfied is still two times bigger than the number of dissatisfied public enterprise workers (Table 2). 
Mihajlov, Dedić, Radovanović, Mihajlov: The differences in job satisfaction among...

Table 2 - Chi-Square Test (sector - how satisfied with your job are you taking everything into consideration?)

Crosstab

\begin{tabular}{|c|c|c|c|c|c|c|c|c|}
\hline & & \multicolumn{6}{|c|}{ How satisfied with your job are you taking everything into consideration? } & \multirow[b]{2}{*}{ Total } \\
\hline & & & & dissatisfied & $\begin{array}{c}\text { very } \\
\text { dissatisfied }\end{array}$ & very satisfied & satisfied & \\
\hline \multirow[t]{2}{*}{ Sector } & public & 3 & 23 & 10 & 0 & 15 & 99 & 150 \\
\hline & private & 0 & 28 & 8 & 5 & 4 & 46 & 91 \\
\hline Total & & 3 & 51 & 18 & 5 & 19 & 145 & 241 \\
\hline
\end{tabular}

\begin{tabular}{lccr}
\hline \multicolumn{3}{c}{ Chi-Square Tests } & \\
\hline \hline & Value & df & $\begin{array}{c}\text { Asymp. Sig. } \\
\text { (2-sided) }\end{array}$ \\
\hline Pearson Chi-Square & $21.285^{\text {a }}$ & 5 &, 001 \\
Likelihood Ratio & 23,824 & 5 &, 000 \\
N of Valid Cases & 241 & & \\
\hline \hline a. 4 cells (33.3\%) have expected count less than 5. The
\end{tabular}

a. 4 cells $(33.3 \%)$ have expected count less than 5 . The

minimum expected count is 1.13 .

Table 3 - Satisfaction among employees in the public and private sector in Serbia

\begin{tabular}{l|ccc}
\hline Determinants of job satisfaction & $\begin{array}{c}\text { Satisfaction among } \\
\text { employees in the pub- } \\
\text { lic sector } \%\end{array}$ & $\begin{array}{c}\text { Satisfaction among } \\
\text { employees in the } \\
\text { private sector } \%\end{array}$ & Difference \\
\hline Direct cooperation with colleagues & 79 & 69 & +10 \\
Time for work completion & 63 & 54 & +9 \\
Support of the managers & 46 & 44 & +2 \\
Presenting ideas to managers & 52 & 42 & +2 \\
Interpersonal relationships & 57 & 53 & +4 \\
Choice of personal way of working & 59 & 62 & -3 \\
Work organization & 41 & 30 & +11 \\
Information withing the organization & 39 & 34 & +5 \\
Working area & 56 & 59 & -3 \\
Opportunity for education & 54 & 55 & -1 \\
Opportunity for job promotion & 25 & 20 & +5 \\
Salary & 49 & 40 & +9 \\
General job satisfaction & 76 & 55 & +21 \\
\hline
\end{tabular}

However, it should be mentioned that there are no statistically significant differences in the distribution of answer frequency among employees in the public and private sector in comparison to the satisfaction with all job aspects. 
Mihajlov, Dedić, Radovanović, Mihajlov: The differences in job satisfaction among...

The majority of more than a half of employees is satisfied by direct cooperation with their colleagues and interpersonal relationships in the enterprise, including the satisfacion with the possibility to choose a personal way of work and education. A fact which brings about concern refers to the fact that only a third of employees from both group of enterprises are satisfied with internal information and with the opportunity for promotion. Although there are no statistically significant differences in the distribution of the respondents' answers in comparison to these claims, data shows that employees in public enterprises in a somewhat larger number $(39 \%)$ in comparison to the employed in the private sector (34\%) evaluate information in the organization as satisfactory, that is, $25 \%$ employees in public enterprises evaluate opportunities for promotion in the organization as satisfactory.

It was found that statistically significant differences exist in the distribution of the frequency of employees' answers from both sectors of the economy in relation to the question "If you would change jobs, what would it be?" From the results of the chi-square test, we read that the distribution of this response is independent of sector respondents, that sector affects how it fits (which is a common response). We conclude, looking at the table that were employed in the public sector determined in their decision to work there, while from the private sector there is a tendency to leave the public sector. To claim there is statistical evidence.

\section{Table 4 - Chi-Square Test (sector - if you would change jobs, what would it be)}

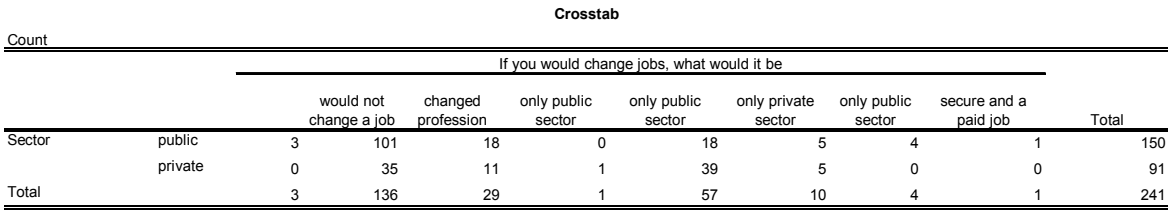

\begin{tabular}{lrrr}
\multicolumn{3}{c}{ Chi-Square Tests } & \\
\hline \hline & Value & df & $\begin{array}{r}\text { Asymp. Sig. } \\
\text { (2-sided) }\end{array}$ \\
\hline Pearson Chi-Square & $38.308^{\text {a }}$ & 7 &, 000 \\
Likelihood Ratio & 40,936 & 7 &, 000 \\
N of Valid Cases & 241 & & \\
\hline \hline $\begin{array}{l}\text { a. } 9 \text { cells (56.3\%) have expected count less than 5. The } \\
\text { minimum expected count is .38. }\end{array}$
\end{tabular}

minimum expected count is 38 .

$67 \%$ respondents from the public sector said that they would not change their jobs, that is, $15 \%$ explicitly said that they intend to keep their current job in the public sector. As opposed to them, 45\% respondents from the private sector would rather work in a public enterprise in comparison to those (38\%) who would not change their existing jobs. Generally speaking, $70 \%$ of all respondents only want to work in the public sector. The specified preference of employees to work in the public sector should be understood in the context of the 
definition of leaving an organization, which as an active dectructive reaction of the employed manifests itself as leaving due to dissatisfaction. More precisely, the possibility is greater that a dissatisfied individual will want to leave his current job unlike the one that expresses a high degree of job satisfaction he performs. Contrary to that, the fact that $43.5 \%$ of respondents in the private sector from the total number of those who expressed general satisfaction with their jobs rather choose to work in some public enterprise, whereas only a small number of them (1.6\%) would stay at their current job positions, is not in favour of the previous ascertainment. The thesis is confirmed only by the data from the public sector where, out of the total number of satisfied workers, only $3 \%$ would work in the private sector while $80 \%$ would not change their current public sector job.

Recent research which deals with the issue of employee's decision to leave or stay in an organization confirms that, among all job aspects, job satisfaction and the feeling of job safety are interpreted as the most important predictors (Clark, 2001) in the sense that the employed who are not satisfied with their salary and the perception of job uncertainty will choose to leave their current jobs.

Figure 2 - General job satisfaction

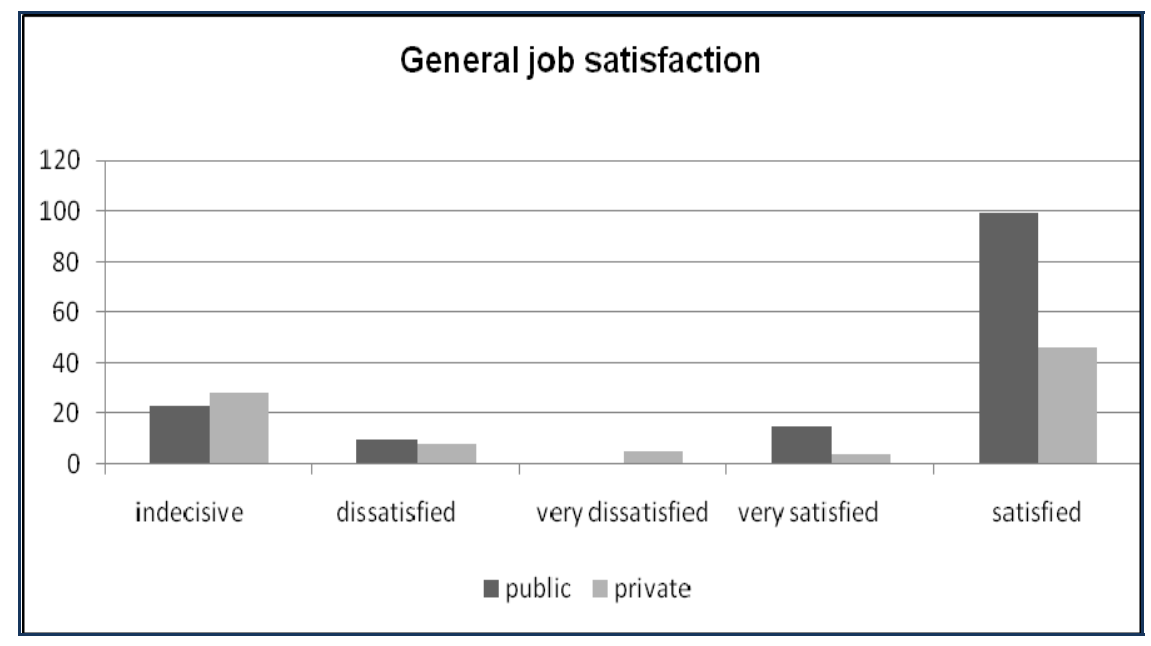

Analysis of the data obtained through this research have not yet determined significant sector differences in the sense of salary satisfaction because majority of more than a half of all respondents express dissatisfaction with this job aspect. The distribution of the answers is statistically insignificant differences by sector respondents. 
Mihajlov, Dedić, Radovanović, Mihajlov: The differences in job satisfaction among...

Table 5 - Chi-Square Test (sector - satisfied with salary)

Crosstab

\begin{tabular}{|c|c|c|c|c|c|c|c|c|}
\hline & & \multicolumn{6}{|c|}{ How satisfied are you with your salary? } & \multirow[b]{2}{*}{ Total } \\
\hline & & & indecisive & dissatisfied & $\begin{array}{c}\text { very } \\
\text { dissatisfied }\end{array}$ & very satisfied & satisfied & \\
\hline \multirow[t]{2}{*}{ Sector } & public & 3 & 18 & 45 & 11 & 4 & 69 & 150 \\
\hline & private & 0 & 14 & 24 & 17 & 2 & 34 & 91 \\
\hline Total & & 3 & 32 & 69 & 28 & 6 & 103 & 241 \\
\hline
\end{tabular}

\begin{tabular}{lccr}
\multicolumn{3}{c}{ Chi-Square Tests } \\
\hline \hline & Value & df & $\begin{array}{c}\text { Asymp. Sig. } \\
\text { (2-sided) }\end{array}$ \\
\hline Pearson Chi-Square & $9.885^{\mathrm{a}}$ & 5 &, 079 \\
Likelihood Ratio & 10,671 & 5 &, 058 \\
$\mathrm{~N}$ of Valid Cases & 241 & & \\
\hline \hline $\begin{array}{l}\text { a. 4 cells (33.3\%) have expected count less than 5. The } \\
\text { minimum expected count is 1.13. }\end{array}$
\end{tabular}

When asked „How satisfied are you with your salary?" $51 \%$ of respondents from the public sector and $60 \%$ from private enterprises gave an unsatisfactory answer or were indecisive. The distribution of answers does not reflect the realistic picture of the great disbalance between the employee standard in the public sector and the private even more because the salary in the public sector is almost $40 \%$ higher than the average registered salary in the rest of the economy, including numerous non-financial privileges and benefits that are available for public sector workers. For these reasons, the existence of significant sector differences in satisfaction with the salary was expected.

However, by further analysis of the responses, an interesting information came up which does not confirm the aforementioned claim that dissatisfaction with the salary implies leaving an organization because respondents from the private sector who are not satisfied with their salary do not intend on changing their current jobs. Almost all respondents explicitly stated their desire to stay in the private enterprise. Contrary to them, more that a half of the respondents (54\%) who, beside general job satisfaction, expressed their intent to leave the private sector are satisfied with their salary, while 15\% were indecisive. Most respondents in the public sector would, despite the dissatisfaction in salary, keep their current jobs in comparison to $3 \%$ of those who justify their preference to work in the private sector by dissatisfaction with almost all job aspects, including the salary. By interpreting the data, a conclusion can be made about the relevant, but not a crucial role of satisfaction with the salary in the intent to leave or stay in the organization exactly because more than a half of the respondents who are satisfied with the salary from the private sector answered „I would work in the public sector". 
Mihajlov, Dedić, Radovanović, Mihajlov: The differences in job satisfaction among...

Figure 2 - Satisfaction with the salary among employees

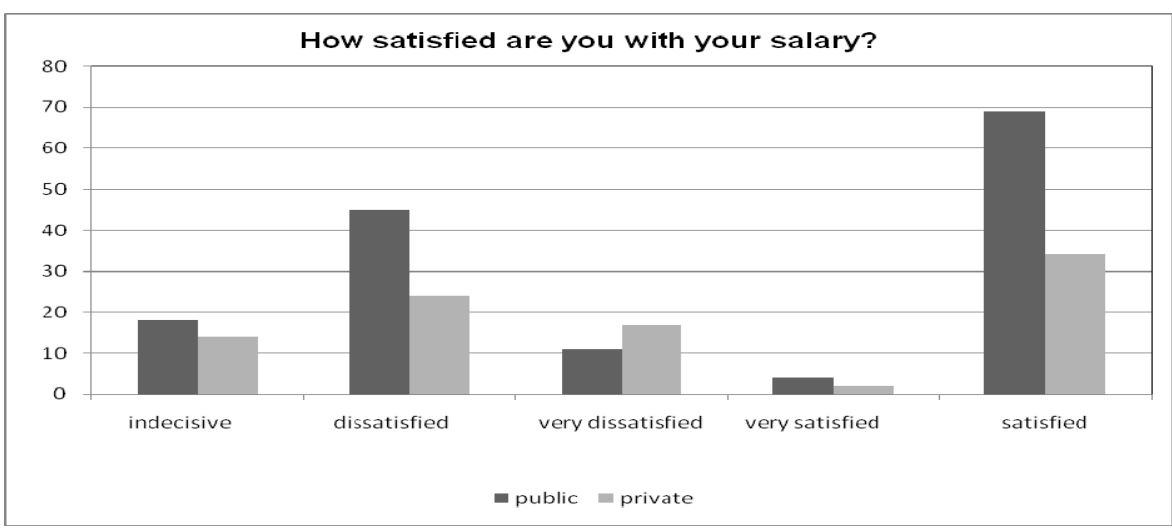

Despite the fact that in the distribution of answers to the question about salary satisfaction there are no statistically significant differences, according to the respondent sector, it can be concluded that employees in the public sector are more satisfied with their salary, whereby the degree of that satisfaction does not significantly affect their intent to leave (keep) their current jobs. The conclusion can also be confirmed by the fact that more than a half of employees in the private sector does not perceive dissatisfaction with the salary as an initial factor for leaving.

Figure 3 - Changing jobs

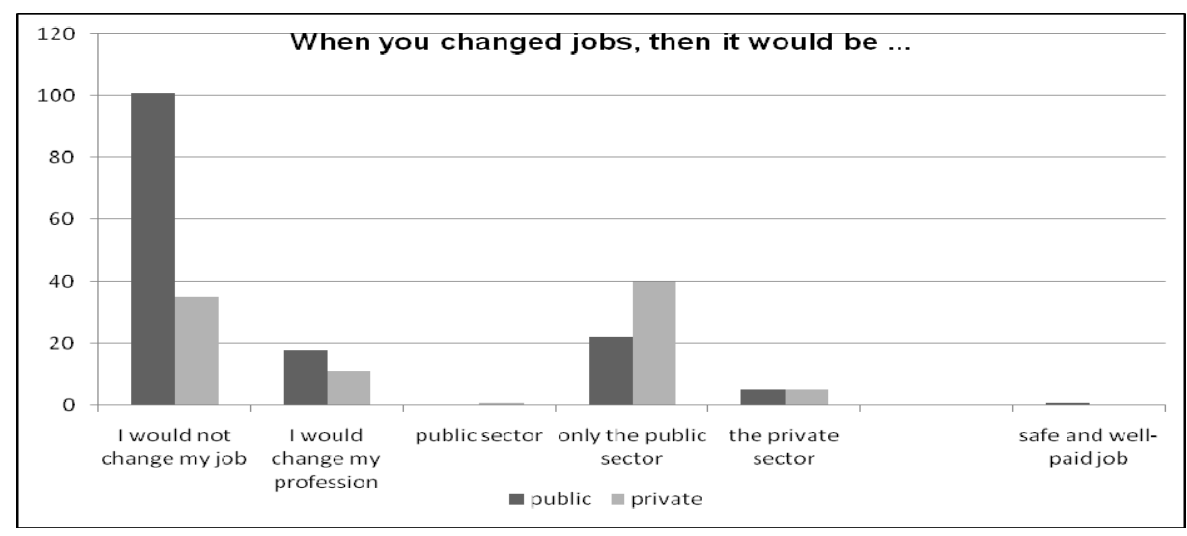

Earlier studies of the sector disbalance in the satisfaction among the employed suggest a significant effect of the job loss risk or job safety on general satisfaction (Hartley, Jacobson, Klandermans \& Van Vuuren, 1991). Employees who feel greater safety are more satisfied with their jobs in comparison to 
the ones who perceive a possible job loss. International experience also warns that the greatest safety is felt by employees who are full-time employed in public institutions, who are isolated (protected) from the possible fluctuation on the labour market, contrary to those who are employed as part-time employees or temporary employees. The central position regarding job safety belongs to those employed in the private sector of the economy (Clark \& Postel-Vinay, 2009). Although the research problem in this paper is not set in the form of a question that would say 'are you satisfied with the job safety', it still seems that the characteristics of our national culture, together with the stereotype about the privatization and entrepreneurs depict the choice of the employed to rather work in public institutions.

As a country in transition, Serbia is still positioned between the past, where job safety withing the socialist self-managed economy was dominant, and the commenced future of market economy. The market and competition as synonyms for freedom in making decisions and the functioning of the mechanisms of the goods, capital and labour markets carry uncertainty in the employment sphere. By being classified as a culture with a high degree of avoiding unsafety which implies a systematic tendency towards formalization, bureaucratization and the creation of an atmosphere which is not enrepreneurial, nor innovative, the period of transit to market economy requires effort in adjusting to the new conditions. This also means accepting facts about lower job safety and indefinite period of time employment and higher demand for temporary and periodical employemnt. On the other hand, the dangerous illusion according to which the only desired career is the one which implies a job contract (with the possibility in the public enterprise) still exists here. Because of this, job safety in the public sector, that is, indefinite time employement is still a very sifnificant category because it hardly feels the effects of the economic crisis, both through lower fall of the salaries and employment in comparison to the rest of the economy. One of the reasons for the public sector immunity for unfavourable trends on the labour market should be looked for in the existence of stronger workers' unions in numerous segments such as great public enterprises or health and education.

The crisis of the social dialog in the private sector which is reflected in the creation of a small number of sector (branch) and collective contracts, including the insufficient concentration and segmentation of unions is not reflected in an adequate protection of the employed in the private sector. The employer is offered a great feedom in determining the salary elements when making job contracts, employee hiring and dismissal and this is why probation work and indefinite time period jobs occur more frequently than in the public sector. Working conditions are usually determined based on the verbal agreement between the employer and the employee. Even when a job contract exists, the conditions which are in it are just formally binding for the employer. The employment inspection does not control the realization of the working condi- 
tions and employees do not have any mechanisms through which they can affect the employer, so working conditions depend both on the objective circumstances (activity type) and on the subjective factors ("goodwill" of the employer). The impression is that exactly based on the existential needs for safety, the society controls general work motivation or the readiness for employment and work and the employer controls the specific work behaviours. Therefore, it is not strange that the growth of job insecurity and unemployment were used by many employers as a significant external source of control of their employees' work behaviour. By offering job contracts for definite periods of time or part-time jobs, employers intend to realize maximum devotion of their employees with minimum personal risks.

\section{Conclusion}

The main hypothesis of this research that the employed in public enterprises are more satisfied than their colleagues in the private sector is confirmed by results of an empirical research. Despite the fact that the analysis of sectoral differences in job satisfaction lack of employees from other public companies, but it was proved that the employed in public enterprises are more satisfied with almost all job aspects when compared to the employed in the private sector despite the fact that there are no statistically significant sector differences in the distribution of answers.

It was shown that general job satisfaction and satisfaction with the salary did not significantly affect the intent of the employed to stay or leave their current jobs. Moreover, more than a half of the employed from the private sector, beside the general job satisfaction, showed the desire to work in public institutions. The fear of losing a job, that is, the insecurity of the job under conditions of still traditional values of employment and insufficient readiness to accept market principles, together with disrespect of work rules and work relationships, makes the employed choose to rather leave the private sector. Sustainability of the negative stereotype about privatization and entrepreneurs in Serbian society should be added to this, through numerous examples of disrespect of basic principles of business ethics.

In accordance with the previous statements, future research could deal with the analysis of conditions for the application of the flexicurity concept on the Serbian labour market. Instead of imposing limitations for the possibility of cancelling individual work contracts and introducing limitations for the use of flexible forms of employment, the concept advocates the removal of obstacles for the creation of new jobs by training workers to accept new employment possibilities and maximum increase of new trends on the labour market. Whether "a temporary, but safe job" will be more attractive than the combination of "constant, but not safe job", that is, whether the work contract length 
will be less important if the fear of losing a job is overcome, requires a different approach in the employment politics through a more active role of the employer. It was shown that on a microlevel, flexicurity is a very significant determinant for the satisfaction of employees, having in mind that more flexibility in employment can contribute to job satisfaction increase only if it does not create negative effects on the perception of business security. In accordance with that, employers can reduce the effects of temporary work contracts on job satisfaction only if an employee is provided with continuity in employment which can, due to lack of contract for an indefinite period of time, be maintained by adequate work conditions which include more opportunities for education, promotion and good internal interpersonal relationships. From the employment policy standpoint, flexibility will not negatively affect the satisfaction of the employed only in conditions when its measures are directed towards favouring the use of flexible forms of employments with the goal to increase stability in employment through an active policy of help to the employed when transferring from one job to another. In general, in conditions of an increasing need for temporary jobs of the labour market, the shift from „,job safety“ (the same job for the whole life) to "employment safety“ (be employed during life by changing organizations or jobs) would weaken the interdependence between less formal business safety and employee satisfaction.

\section{References}

"Public service? No, thanks, I am an entrepreneur!" Citizens' initiatives, Belgrade, 2012.

Labour force survey for 2010, (2011), The statistical office of the Republic of Serbia, Beograd.

Clark, A. E., Senik, S. (2006), "The (Unexpected) Structure of 'Rents' on the French and British Labour Markets," Journal of Socio-economics, 35 (2), pp.180-196.

Clark, A. E. (2001), What really matters in a job? Hedonic measurement using quit data, Labour Economics, 8, pp. 223-242; Audit Commission, 2002. Recruitment and retention: a public service workforce for the twenty-first century. url: http://www.audit-commission.gov.uk/reports

Clark, A. E., Postel-Vinay, F. (2009), Job Security and Job Protection, Oxford Economic Papers, 61, 2, pp. 207-239.

Demoussis, M., Giannakopoulos, N. (2007), "Exploring Job Satisfaction in Private and Public Employment: Empirical Evidence from Greece." Labour, 21 (2), pp. 333359.

Ghinetti, P., (2006), „The Public-Private Job Satisfaction Differential in Italy,“ Istituto di Economia dell'Impresa e del Lavoro Facoltà di Economia, Università Cattolica del Sacro Cuore, Milano.

Hartley, J., Jacobson, D., Klandermans, B., Van Vuuren, T. (1991), Job insecurity: Coping with jobs at risk. London: Sage Publications.

Herzberg, F., Mausner, B., Sniderman, B. (1959), The motivation to work, Willey. 
Mihajlov, Dedić, Radovanović, Mihajlov: The differences in job satisfaction among...

Ivancevich, J. M., Olekalns, M., Matteson, M. T. (1997), Organizational behavior and management. Sydney: Irwin; p. 86.

Report on small and medium enterprises and entrepreneurship in 2008, Ministry for economy and regional development, Republic agency for development of SME and entrepreneurship, Belgrade, pg.9.

Report on small and medium enterprises and entrepreneurship in 2009, Ministry for economy and regional development, Republic agency for development of SME and entrepreneurship, Belgrade, pg.10.

Judge T. A, Watanabe S. (1994), „Individual differences in the nature of relationship between job and life satisfaction," Journal of Occupational and Organizational Psychology, 67, pp.101-107.

Kanellopoulos, C. N. (1997), „Public-private wage differentials in Greece”, Applied Economics, 29, pp. 1023-1032.

Kates, S. L., (1950), „Rorschach Responses, Strong Blank Scales and Job Satisfaction among Policemen," Journal of Applied Psychology, 34/4, pp. 249-254.

Kioulafas, K., Donatos, G., Michailidis, G. (1991), „Public and private sector wage differentials in Greece," International Journal of Manpower, 12, pp. 9-14.

Kreitner, R., Kinicki, A., Buelens, M. (1999), Organisational behaviour, Berkshire: McGraw Hill.

Luechinger, S., Meier, S., Stutzer, A. (2008), "Bureaucratic Rents and Life Satisfaction," Journal of Law, Economics and Organization, 24 (2), pp. 476-488.

Matanović, J. (2009), „Osobine ličnosti kao prediktori zadovoljstva poslom“, Primenjena psihologija, 2(3), str. 327-338.

Nathan A. Bowling, G., Hammond, D. (2008), „A meta-analytic examination of the construct validity of the Michigan Organizational Assessment Questionnaire Job Satisfaction Subscale," Journal of Vocational Behavior, 73/1, pp. 63-77.

Papapetrou, E. (2006), „The unequal distribution of the public-private sector wage gap in Greece: evidence from quantile regression", Applied Economics Letters, 13, pp. 205-210.

Sheridan J., Slocum, J., (1975), „Motivational determinants of job performance,“ Journal of Applied Psychology, 60(1).

Sverke, M., Hellgren, J. (2002), „The nature of job insecurity: Understanding employment uncertainty on the brink of a new millennium," Applied Psychology: An International Review, 51, pp. 23-42.

Labour Law of the Republic of Serbia, (2005), Official Gazette, 24/05 and 54/09.

Weiss, H. M., (2002), „Deconstructing job satisfaction: separating evaluation, beliefs and affective experiences“, Human Resourse Management Review, 12, pp. 173194.

TNS Medium Gallup. (2008). Global Study Voice of the People (c) - Security of job. Retrieved from http://www.tnsmediumgallup.co.rs 